\title{
How Daily FSSB and Ethical Leadership Affect Work Stress for Chinese Public Servants
}

\author{
Liu Chongrui ${ }^{1}$, Zhang Cheng ${ }^{2 *}$, Wang Cong ${ }^{2}$, Wang Hongjie ${ }^{1}$, Chen Jizhou ${ }^{1}$ \\ ${ }^{1}$ Department of Management, Beijing Electronic Science and Technology Institute, Beijing, China \\ ${ }^{2}$ Department of Economics and Management, Beijing City University, Beijing, China
}

\begin{abstract}
Employees' work stress has been studied extensively. This study investigates how day-to-day family supportive supervisor behaviors (FSSB hereafter) affect daily subordinates' work stress. 137 employees responded to daily surveys for 10 days. With a total of 1370 surveys, the results showed that daily FSSB was positively related to daily subordinates' positive emotions, and ethical leadership positively moderated the relationship between the two. In addition, daily FSSB and daily subordinates' positive emotions had negative effect on daily work stress, which provided evidence that daily subordinates' positive emotions played a mediating role in the relation of daily FSSB and daily work stress.
\end{abstract}

\section{INTRODUCTION}

As work stress is more and more becoming a key factor influencing employees' psychological and physical state (Nielsen et al., 2008). How to relieve employees' work stress has attracted significant attention in organizational research. In workplace, co-workers and supervisors play an important role in deviating subordinates' stress (Sloan, 2012; Edwards, 1999). Actually, Supervisors' support plays a more important role in relieving subordinates' work-related stress (e.g., Yang et al., 2015). In particular, supervisors' family supports increasingly make a massive contribution under the current circumstance that the majority of employees act family roles as well as work role simultaneously (Thomas \& Ganster, 1995). Behson (2005) proposed that compared to other variable of organizational family-related support, FSSB contributed to more variance in employee stress.

The Affective Events Theory (AET hereafter) holds that events happening in organizational environment could stimulate organizational members' emotion, which in turn lead to a serious of emotion-driven behaviors, attitudes and cognitive judgments ( Weiss \& Cropanzano, 1996; Lee et al., 2017). A mass of empirical evidence supported the mediating role of emotions in the relationships between work-related events and employee's outcomes (e.g. Tremmel, Sonnentag, \& Casper, 2018). In the same vein, we inferred that, FSSB that acts as a positive event provide a supportive and enjoying environment, Lee et al. (2017) claimed that an enjoying environment is beneficial to employees' positive emotions, which in turn, relieve employees' perception of stress.

Moreover, the leader trait making an underlying effect on the influence of FSSB on subordinates' outcomes is deserved to be concerned. Ethical leadership has been proved to be a key variable in affecting employees' outcomes by a considerable amount of research (e.g., Piccolo et al. 2010). In specially, some scholars investigated the moderating effect of ethical leadership at work (e.g. Lu \& Guy, 2014; Eissa \& Wyland, 2018), for example, Eva et al. (2018) investigated that ethical leadership moderated the relationship between organizational support and follower work behaviors; Joplin et al. (2019) provided empirical evidence that ethical Leadership played a moderating role in the relationship of entitlement and work engagement. However, the major of ethical leadership research has been conducted in Western countries, more researches on ethical leadership are called for in Chinese culture that labeled collectivism, team orientation, and harmonious relationships (e.g. Walumbwa et al., 2011). This study aims to consider ethical leadership as a situational condition and investigate the moderating role in Chinese culture.

To sum up, in line with AET, FSSB functions as a positive events for facilitating subordinates' positive emotions and in turn relieve work stress. In addition, if the leader is an ethical leadership, the leaders' supportive behavior will more strongly generate subordinates' positive emotions. Therefore, this study was aimed to evaluate a model specifying the role of FFSB in relieving subordinates' work stress by the method of ESM, which could respond to Kossek et al.'s (2011, p. 304) assertion that "none of the studies in our database considered how perceptions of workplace support cascade across levels of analysis". In addition, some scholars claimed that AET also emphasize the necessary of exploring within-person experiences (Weiss \& Cropanzano, 1996). This study addresses the within-individual relationship of FSSB and subordinates' work stress as mediated by positive 
emotions, as well as the cross-level moderating role of ethical leadership.

\section{LITERATURE REVIEW AND HyPOTHESIS}

\subsection{FSSB}

As early as the 1950s, researchers have suggested that employees in perceptions of being supported tend to form a various of positive work outcomes. Among a variety of supports, FSSB could provide a serious of supportive actions enabling employees to satisfying work and family demands simultaneously (Kossek et al., 2011). Based on AET, emotions stem from specific events (Lazarus \& Cohen-Charash, 2001), positive events generate employees' positive emotions, and negative events lead to negative emotions. It is no doubt that FSSB considered as a positive events will benefit to employees' positive emotional states. Majdar, Oldham and Pratt (2002) provide an empirical support that leader support was related to subordinates' positive emotions.

\subsection{Ethical leadership}

Leaders are important in influencing and changing subordinates' beliefs, attitudes, and core values. Ethical leader is such leader who act ethically in personal actions and promote the conduct to his employees through "twoway communication, reinforcement, and decisionmaking" (Brown et al., 2005, p. 120). Ethical leaders have a serious trait such as honest, fairness, trustworthy and concerned about their followers, which provide a supportive, trust and pleasant context for employees to generate positive emotions such as happiness (Mayer et al., 2012).

\subsection{Subordinates' positive emotions}

The significance of positive emotions in workplace has been proved in both empirical studies and reviews, for example, positive emotions is helpful to establish social support networks, set challenging goals (Fredrickson 2004; Ilies \& Judge, 2005). There are also research supporting the adaptive functions of positive emotion during stress (Fredrickson \& Losada, 2005). A mass of empirical studies provide evidence that positive emotion contribute greatly to individuals' resilience and adaptation to stress (e.g., Folkman \& Moskowitz, 2000). The broaden-and-build theory also provide a theoretical perspective on how positive emotions relieve individuals' work stress through expanding one's scope of attention and cognition (Fredrickson, 2001).

\section{MethodologY}

\subsection{Research Goal}

This study was intended to investigate how daily FSSB influence subordinates' positive emotions and work stress, furthermore, how ethical leadership take a moderating role. The hypotheses are proposed as following:

H1: within-individual, daily FSSB is positively related to daily subordinates ' positive emotions.

H2: Ethical leadership has a moderating effect on the relations between daily FSSB and daily subordinates' positive emotions.

H3: within-individual, daily FSSB is negatively related to daily work stress.

H4: within-individual, daily subordinates' positive emotions is negatively related to daily work stress.

The theoretical model is showed in Figure 1.

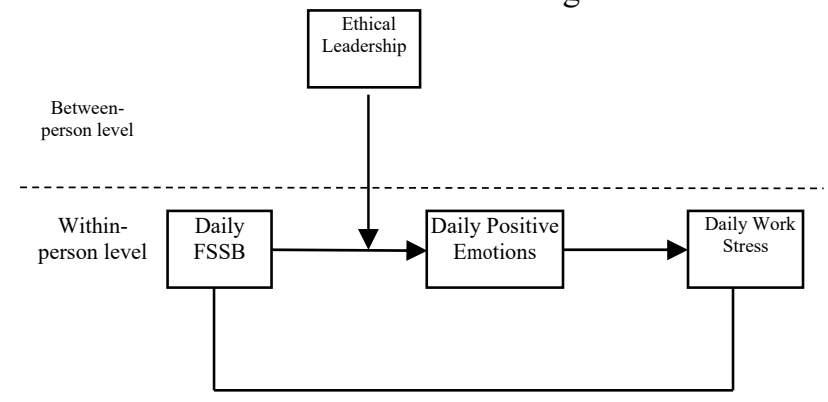

Figure 1. The Theoretical Model

\subsection{Sample and Data Collection}

The sample consisted of 137 full-time public servants in China (68 females and 69 males). 161 potential participants registered their interest originally. Considering variant work schedules, participants were allowed to complete this survey at the end of the working day, anytime between 4 p.m. to 10 p.m. each day. The participants were asked to complete one survey each day for 10 working days. Finally, 137 participants completed the study ( $85 \%$ response rates).

\subsection{Measurement}

FSSB Leaders' family supportive supervisor behavior was assessed with a four-item measure developed by Hammer et al. (2013).

Positive Emotions Subordinates' positive emotions were measured with a 5-item measure selected from Watson et al.'s (1988) PANAS scale.

Work stress Work stress was measured by the scale adopted from Motowidlo, Packard, \& Manning (1986).

Ethical leadership Ethical leadership was measured with Brown et al.' (2005) Ethical leadership Scale (ELS). Because ethical leadership is a between-person level variable in this study, we averaged the data for 10 working days of each sample to form a broad and stable measure of ethical leadership. 
The questionnaire was designed with Likert-type scale. The scale of FSSB, ELS, and work stress ranged from 1 (strongly disagree) to 5 (strongly agree), the scale of positive emotion ranged from 1(rarely) to 5 (very often). Data were analyzed by SPSS.

\section{DATA ANALYSIS AND FINDINGS}

Table 1 shows means, standard deviations and correlations of the variables. The alpha reliability for all the scales range from 0.89 to 0.94 , which indicated satisfactory reliability.

TABLE I. CORRELATIONS, AlPHA RELIABILITIES AND Descriptive Statistics

\begin{tabular}{|c|c|c|c|c|c|c|c|}
\hline Variable & $\mathrm{M}$ & $\mathrm{SD}$ & 1 & 2 & 3 & 4 & 5 \\
\hline Level 1 & & & & & & & \\
\hline 1. FSSB & 3.89 & 1.22 & $(0.91)$ & $0.59^{* *}$ & $-0.32^{* *}$ & $0.94^{* *}$ & -0.03 \\
\hline 2.Positive emotions & 4.50 & 0.85 & $.48^{* *}$ & $(0.89)$ & $-0.37^{* *}$ & $0.59^{* *}$ & 0.04 \\
\hline 3.Work stress & 2.39 & 0.97 & $-.20^{* *}$ & $-.25^{* *}$ & $(0.94)$ & $-0.35^{* *}$ & 0.00 \\
\hline Level 2 & & & & & & & \\
\hline 4.Ethical leadership & 4.03 & 1.17 & & & & $(0.90)$ & -0.03 \\
\hline 5.gender & 1.5 & 0.50 & & & & & - \\
\hline
\end{tabular}

Note: Gender $(1=$ Female, $2=$ Male $)$. Cronbach's alpha coefficients are in parentheses along the diagonal. Correlations above the diagonal are between-individual correlations $(\mathrm{N}=137)$. Correlations below the diagonal are within-individual correlations $(\mathrm{N}=1370)$. ${ }^{*} \mathrm{p}<0.05$. $* *$ $\mathrm{p}<0.01$

The intra - and inter - individual variation of work stress was examined. The results showed that the intraindividual variation of work stress was 0.52 , accounting for $56 \%$ of the total variance, and the inter-individual variation was 0.41 . The inter - individual variation of subordinates' positive emotion was 0.27 , accounting for $54 \%$ of the total variation, which indicating that the dayto-day variation contribute most variance of outcome variables.

Results of the regression analyses are presented in Table 2, Table 3, Table 4 and Table 5.

TABLE II. EFFECTS OF FSSB ON SUBORdinAtEs' Positive EMOTIONS

\begin{tabular}{|c|c|c|c|}
\hline $\begin{array}{c}\text { Model 1' } \\
\text { independence } \\
\text { variable: FSSB }\end{array}$ & $\begin{array}{c}\text { Standardized } \\
\text { Coefficients }\end{array}$ & T & Sig \\
\cline { 2 - 3 } & Beta & \\
\hline (constant) & & 45.09 & .000 \\
\hline FSSB & 0.48 & 20.30 & .000 \\
\hline $\mathrm{R}^{2}$ & & 0.23 & \\
\hline $\mathrm{F}$ & & 412.26 & .000 \\
\hline
\end{tabular}

TABLE III. MODERATING EFFECTS OF ETHICAL LEADERSHIP

\begin{tabular}{|c|c|c|c|}
\hline $\begin{array}{c}\text { Model 2' } \\
\text { independence } \\
\text { variable: FSSB }\end{array}$ & $\begin{array}{c}\text { Standardized } \\
\text { Coefficients }\end{array}$ & \multicolumn{2}{|c|}{ Sig } \\
\cline { 2 - 3 } & Beta & \\
\hline (constant) & & 40.33 & .000 \\
\hline FSSB & 0.36 & 21.41 & .000 \\
\hline FSSB*EL & 0.16 & 7.09 & .000 \\
\hline $\mathrm{R}^{2}$ & & 0.26 & \\
\hline $\mathrm{F}$ & & 238.71 & .000 \\
\hline
\end{tabular}

TABLE IV. EFFECTS OF FSSB ON WORK STRESS

\begin{tabular}{|c|c|c|c|}
\hline $\begin{array}{c}\text { Model 3' } \\
\text { independence } \\
\text { variable: } \\
\text { FSSB }\end{array}$ & $\begin{array}{c}\text { Standardized } \\
\text { Coefficients }\end{array}$ & & Sig \\
\cline { 2 - 3 } & Beta & & \\
\hline (constant) & & 31.80 & .000 \\
\hline FSSB & -0.20 & -7.38 & .000 \\
\hline $\mathrm{R}^{2}$ & & 0.04 & \\
\hline $\mathrm{F}$ & & 54.53 & .000 \\
\hline
\end{tabular}

TABLE V. EFfects of SubordinAtes' Positive Emotions ON WORK STRESS

\begin{tabular}{|c|c|c|c|}
\hline $\begin{array}{c}\text { Model 4' } \\
\text { independence } \\
\text { variable: } \\
\text { subordinates' } \\
\text { positive emotions }\end{array}$ & $\begin{array}{c}\text { Standardized } \\
\text { Coefficients }\end{array}$ & T & Sig \\
\cline { 2 - 4 } & Beta & \\
\hline (constant) & -0.25 & -9.60 & .000 \\
\hline $\begin{array}{c}\text { subordinates' } \\
\text { positive emotions }\end{array}$ & & 0.06 & \\
\hline $\mathrm{R}^{2}$ & & 92.16 & .000 \\
\hline $\mathrm{F}$ & & & \\
\hline
\end{tabular}

According to the results, FSSB affected subordinates' positive emotions positively, ethical leadership positively moderated the relationship between FSSB and subordinates' positive emotions. It was also found out that FSSB and subordinates' positive emotions had a significantly negative effect on work stress. In addition, the findings indicated that subordinates' positive emotions mediated the relation between FSSB and work stress, ethical leadership moderated the mediating mechanism, which partially implied that leaders' family supportive behavior generated subordinates' positive emotions which in turn reduced work stress, especially, the effect was stronger when the leader was an ethical leader. 


\section{Discussion}

This study aimed to investigate the effects of work related family-support on subordinates' work stress which was mostly universal in organizations. Specifically, we concentrated on the effects of subordinates' emotions in this study. AET proposed that workplace events can generate individuals' emotions, and then influence subordinates' judgments, behaviors and attitudes toward the work itself (Weiss \& Cropanzano, 1996). This study found that FSSB positively influenced subordinates' positive emotions. This implies that the support of managers as a positive event can reduce work stress while generating positive emotions for subordinates. In addition, moral leadership will have a stronger impact on relationship.

To our best know, there exists no similar study. However, there were not without limitations in this study. First, we don't conclude negative emotions. Although the majority of research has concluded that negative emotions lead to negative individuals' consequences, there are still some scholars arguing that negative emotions may also lead to positive outcomes (e.g. Grandey, 2008; George \& Zhou, 2002). Second, the data were selected from a single-source, which may incur the threats of common source bias. Despite these limitations, the result in this study provide important theoretical and practical implications for developing stress management programs.

\section{REFERENCES}

1. Eva, N., Newman, A., Miao, Q., Wang, D., and Cooper, B. (2018). "Antecedents of Duty Orientation and Follower Work Behavior: The Interactive Effects of Perceived Organizational Support and Ethical Leadership. "Journal of Business Ethics, 2018, in press.

2. Behson, S. J. (2005). "The relative contribution of formal and informal orga-nizational work-family support. "Journal of Vocational Behavior, 66(3), pp. 487-500.

3. Brown, M. E., Trevino, L. K., and Harrison, D. A. (2005). "Ethical leadership: A social learning perspective for construct development and testing." Organizational Behavior and Human Decision Processes, 97, pp. 117-134.

4. Edwards, J. R., and Rothbard, N. P. (1999). "Work and family stress and well-being: An. examination of person-environment fit in the work and family domains. " Organ Behav Hum Decis Process, 77, pp. 85-129.

5. Eissa, G. , and Wyland, R. (2018). "Work-family conflict and hindrance stress as antecedents of social undermining: does ethical leadership matter?" Applied Psychology. 67(4), pp. 645-654.

6. Folkman S, and Moskowitz J. T. (2000). "Positive affect and the other side of coping." American Psychologist. 55, pp. 647-654.
7. Fredrickson, B. L. (2001). "The role of positive emotions in positive psychology: The broaden-andbuild theory of positive emotions. "American Psychologist, 56, pp. 218-226.

8. Fredrickson, B. L. (2004). "Gratitude, like other positive emotions, broadens and builds." In R. A. Emmons \& M. E. McCullough (Eds.). The psychology of gratitude (pp. 145-166). New York: Oxford University Press.

9. Fredrickson, B. L., and Losada, M. F. (2005). "Positive affect and the complex dynamics of human flourishing. "American Psychologist, 60 (7), pp. 678-686.

10. George, J. M., and Zhou, J. (2002). "Understanding when bad moods foster creativity and good ones don't: The role of context and clarity of feelings." Journal of Applied Psychology, 87, pp. 687-697.

11. Grandey, A. (2008). Emotions at work: A reviewand research agenda. In J. Barling \& C. L. Cooper (Eds.), The Sage handbook of organizational behavior (Vol. 1, pp. 235-261). London: SAGE.

12. Hammer, L. B., Ernst, K. E., Bodner, T., and Crain, T. (2013). "Measurement development and validation of the family supportive supervisor behavior short-form." Journal of Occupational Health Psychology, 18(3), pp. 285-296.

13. Ilies, R., and Judge, T. A. (2005). "Good regulation across time: The effects of feedback and affect." Journal of Applied Psychology, 90, pp. 453-467.

14. Joplin, T., Greenbaum, R. L., Wallace, J. C., and Edwards, B. D. (2019). "Employee entitlement, engagement, and performance: the moderating effect of ethical leadership. " Journal of Business Ethics, in press.

15. Kossek, E. E., Pichler, S., Bodner, T., and Hammer, L. B. (2011). "Workplace social support and workfamily conflict: A meta-analysis clarifying the influence of general and work-family-specific supervisor and organizational support. "Personnel Psychology, 64, pp. 289-313.

16. Lazarus, R. S., and Cohen-Charash, Y. (2001). "Discrete emotions in orga-nizational life. In R. L. Payne \& G. L. Cooper (Eds.). " Emotions at work: Theory, research, and applications for management (pp. 45-81). Chichester, UK: Wiley.

17. Lee, Y., Kim, S., and Kim, H. (2017). "Personenvironment fit and its effects on employees' emotions and self-rated / supervisor-rated hotel restaurants." International Journal of Contemporary Hospitality Management, 29(5), pp. 1447-1467.

18. Lu, X. J., and Guy M. E. (2014). "How emotional labor and ethical leadership affect job engagement for Chinese Public servants. " Public Personnel Management, 43(1), pp. 3-24.

19. Majdar, N., Oldham, G. R., and Pratt, M. G. (2002). "There's no place like home? The contributions of work and nonwork creativity support to employees' 
creative performance." The Academy of Management Journal, 45(4), pp. 757-767.

20. Mayer, D. M. , Aquino, K. , Greenbaum, R. L. , and Kuenzi, M. . (2012). "Who displays ethical leadership, and why does it matter? an examination of antecedents and consequences of ethical leadership." Academy of Management Journal, 55(1), pp. 151-171.

21. Motowidlo, S. J., Packard, J. S., and Manning, M. R. (1986). "Occupational stress: Its causes and consequences for job performance." Journal of Applied Psychology, 71(4), pp. 618.

22. Nielsen, N. R., Kristensen, T. S., Schnohr, P., and Gronbaek, M. (2008). "Perceived stress and causespecific mortality among men and women: results from a prospective cohort study." American Journal of Epidemiology, 168(5), pp. 481-491.

23. Piccolo, R. F., Greenbaum, R., Den Hartog, D. D., and Folger, R. (2010). "The relationship between ethical leadership and core job characteristics." Journal of Organizational Behavior, 31, pp. 259-278.

24. Sloan, M. M. (2012). "Unfair treatment in the workplace and worker well-being: The role of coworker support in a service work environment." Work Occup, 39, pp. 3-34.

25. Thomas, L. T., and Ganster, D. C. (1995). "Impact of family-supportive work variables on work-family conflict and strain: A control perspective." Journal of Applied Psychology, 80(1), pp. 6-15.

26. Tremmel S., Sonnentag S., and Casper A. (2018) "How was work today? interpersonal work experiences, work-related conversations during afterwork hours, and daily affect." Work \& Stress, pp. 121.

27. Walumbwa, F. O., Mayer, D. M., Wang, P., Wang, H., Workman, K., and Christensen, A. L. (2011). "Linking ethical leadership to employee performance: The roles of leade-member exchange, self-efficacy, and organizational identification." Organizational Behavior and Human Decision Processes, 115, pp. 204-213.

28. Watson, D., Clark, L. A., and Tellegen, A. (1988). "Development and validation of briefmeasures of positive and negative affect: The PANAS scales." Journal of Personality \& Social Psychology, 54, pp. 1063-1070.

29. Weiss, H. M., and Cropanzano, R. (1996). "Affective events theory: a theoretical discussion of the structure, causes and consequences of affective experiences at work", Research in Organizational Behavior, 18, pp. 1-74.

30. Yang, T., Shen, Y. M., Zhu, M., Liu, Y., Deng, J., and Chen, Q., et al. (2015). "Effects of co-worker and supervisor support on job stress and presenteeism in an aging workforce: a structural equation modelling approach." International Journal of Environmental Research \& Public Health, 13(1), pp. 1-15. 